\title{
Temporal water table changes in soil toposequence of the Poznań Lakeland (western Poland)
}

\begin{abstract}
The paper presents results of determination of temporal changes in water table depths in the toposequence of Retisols/ Luvisols and Phaeozems/Gleysols. Assessment of temporal trends in the water table depth was made with the use of the linear regression analysis. The results obtained indicate that the mean water table depth and mean high and low water table depths were deeper in the soil at the upper part of the slope in comparison with soil located at the footslope. A higher amplitude of water table was observed in Retisols than in Gleysols but the highest variability of water table level was noted in the soils at the footslope compared to those at the slope summit. In Retisols, with each month of observation from 1993 to 2012, the water table showed a tendency to increase. These trends were the highest from January to April, which may be related to the tendency of increasing monthly sums of precipitation in December, January and February. In the Gleysol at the footslope, in the period 1993-2012 and in the vegetation season, the water table depth showed a tendency to decrease. This trend may be due to the impact of water table on the soil water content at the root zone, which is used in the process of evapotranspiration.
\end{abstract}

Keywords: Retisols, Gleysols, toposequence, water table trend

\section{INTRODUCTION}

The water table depth is one of the most important indicators of environmental conditions. Hence, much effort has been devoted to the issues of temporal as well as spatial water level variability. Many authors have emphasized a relationship between groundwater level fluctuations and climatological parameters (Khan and Fenton 1994, Almedeij and Al-Ruwaih 2006, Morgan and Stolt 2006, Jan et al. 2007, Chen et al. 2002) and location of wells in the relief (Buol et al. 2011, Hanna et al. 1983, Simonson and Boersma 1972, Zobeck and Ritchie 1984). In forest soils that developed from sandy parent material in the Wielkopolska region a trend of decreasing water table was observed in the 2000-2010 period (Stasik et al. 2016). In contrast, in the Kampinos National Park in the period 1999-2013, no significant trends in water table change were observed (Krogulec and Zabłocki 2015). The spatial and temporal variability of the water table depth is one of the most important features affecting plant cultivation, water management and protection as well as formation of water and soil resources. This issue is particularly important in terms of climate change and the associated forecasts of a general decrease in water table depths (IPCC 2014). The decreasing water table can contribute to the changes in soil water regime (Komisarek and Kozłowski 2008). According to Kędziora (2008), in Wielkopol- ska region these climatic changes are expressed mainly by an increase in air temperature, deficit of water vapor pressure, and increase in relative sunshine and wind speed. Therefore, a significant increase in evapotranspiration is the main reason for a lowering of lakes water level as well as water table depth in catchments.

In this study, a simple linear regression analysis was applied in order to characterize temporal trends in water table depth in arable soils typical of the Polish Lowlands. Identification of the relationships between the soil location (wells) on the slope and water table trends can be a good starting point for modelling and optimization of both balanced plant production and protection as well as the formation of water and soil resources.

The aim of this study was to determine trends of water table depth in Retisols developed in upper part of the slope and Gleysols formed on the footslope.

\section{MATERIALS AND METHODS}

The study was carried out in the cultivated catchment area of the Przybroda Experimental Station of Poznan University of Life Sciences located in the north-central part of the Poznań Lakeland on within the Szamotuly Plain. This area is a part of the undulating ground moraine of the Poznan Phase of Vistulian Glaciation. In this area, the Retisols/Luvisols and the 
Phaeozems/Gleysols form soil sequences along slopes. Soil sequences of this kind occur not only in the Poznan Lakeland but also throughout the Polish Lowlands.

At the beginning of the study, the soil cover variability of the catchment area was determined (Marcinek et al. 1998). Then, the locations of representative pedons ( 6 pedons) were selected (Fig. 1$)$. The pedons constituting the stationary sites of measurements were instrumented with wells constructed of $80 \mathrm{~mm}$ polyvinyl chloride (PCV) pipe. The wells were installed using a hand auger and sealed with a shield tube at the ground surface to prevent surface water infiltration and percolation along the side of the well. The present study covered two stationary measurement pedons, i.e.: Eutric Albic Glossic Retisols (Loamic, Aric, Cutanic, Ochric) (P1) developed in upper part of the slope and Eutric Mollic Subaquatic Gleysols (Abruptic, Loamic, Aric, Drainic, Humic, Raptic) (P6) formed within the footslope (IUSS Working Group 2015) (Fig. 1). Soil P6 has developed from fluvioglacial material and soil P1 from a glacial till. Taxonomic soil diversity is related to its position on the slope and thus to the water table depth.
Water table depths were measured every two weeks from January 1993 to December 2012. It was the longest continuous seasonal investigation of the water table in the Polish Lowlands catena. Meteorological data were collected at the same time. Mathematical and statistical calculations were performed using the software Statistica ver. 10.

\section{RESULTS AND DISCUSSION}

The temporal changes in water table depth and precipitation in the investigated soils are presented in Fig. 2. At the beginning of 1993, the water table in P1 well, located in upper part of the slope, reached the lowest depth (below $400 \mathrm{~cm}$ ) noted throughout the period of measurements (1993-2012). The lowest water table depths in 1993 were caused by low precipitation in $1992(406 \mathrm{~mm})$. Also at the end of 2004 and early 2005, the water table depths close to $400 \mathrm{~cm}$ below surface were observed. This suggests that the water table depth in a given year is determined not only by weather conditions in a given year, but also by the weather conditions in previous years, which is

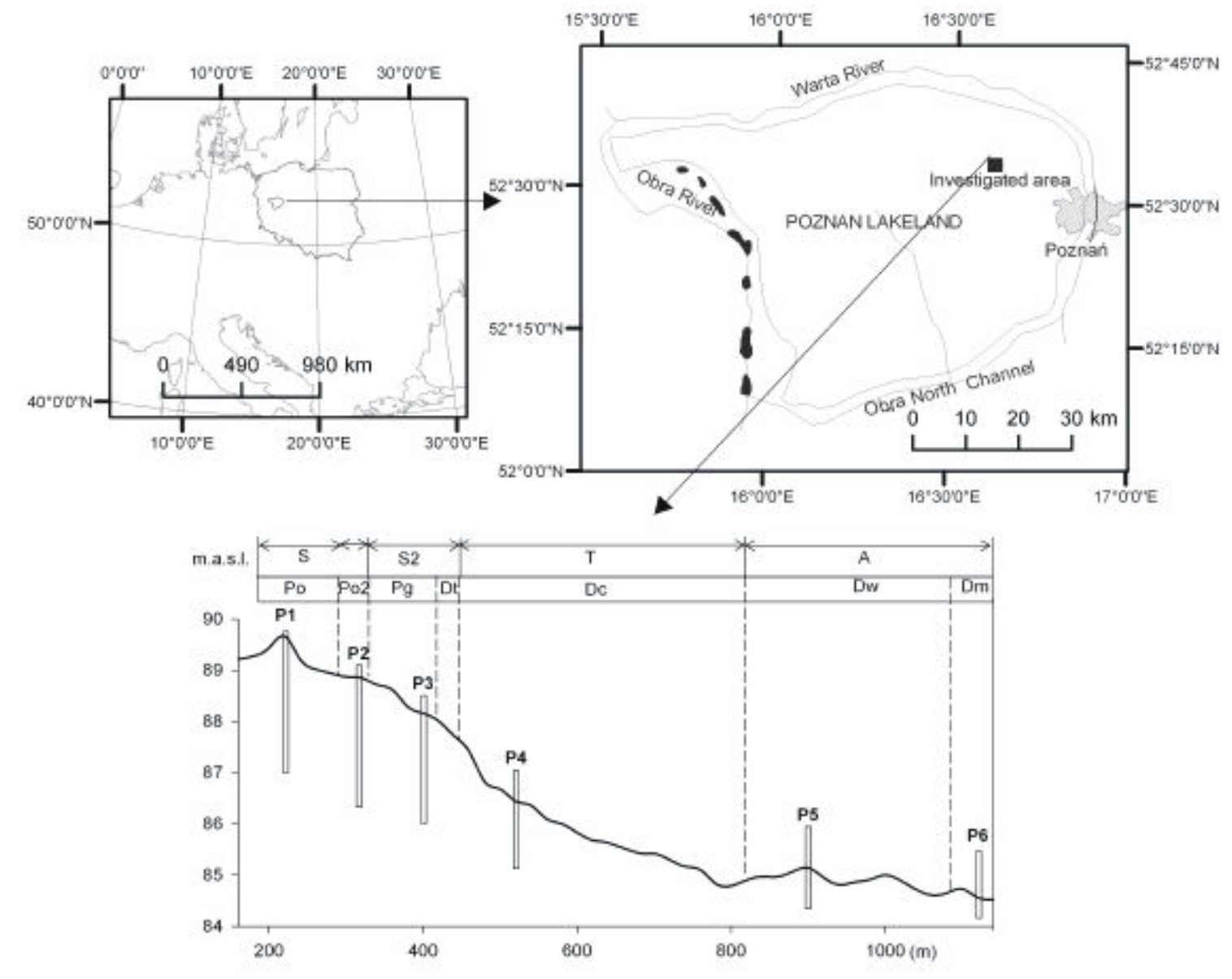

FIGURE 1. Location of investigated area and distribution of wells in the soil catena: $\mathrm{S}$ - summit, $\mathrm{S} 2$ - shoulder, $\mathrm{T}$ - pediment, A - footslope, Po - Eutric Albic Retisols, Po2 - Albic Luvisols, Pg - Gleyic Luvisols, Dt - Luvic Gleyic Phaozems, Dc - Cambic Gleyic Endocalcic Phaozems, Dw - Eutric Endocalcic Mollic Gleysols, Dm - Eutric Mollic Subaquatic Gleysols 


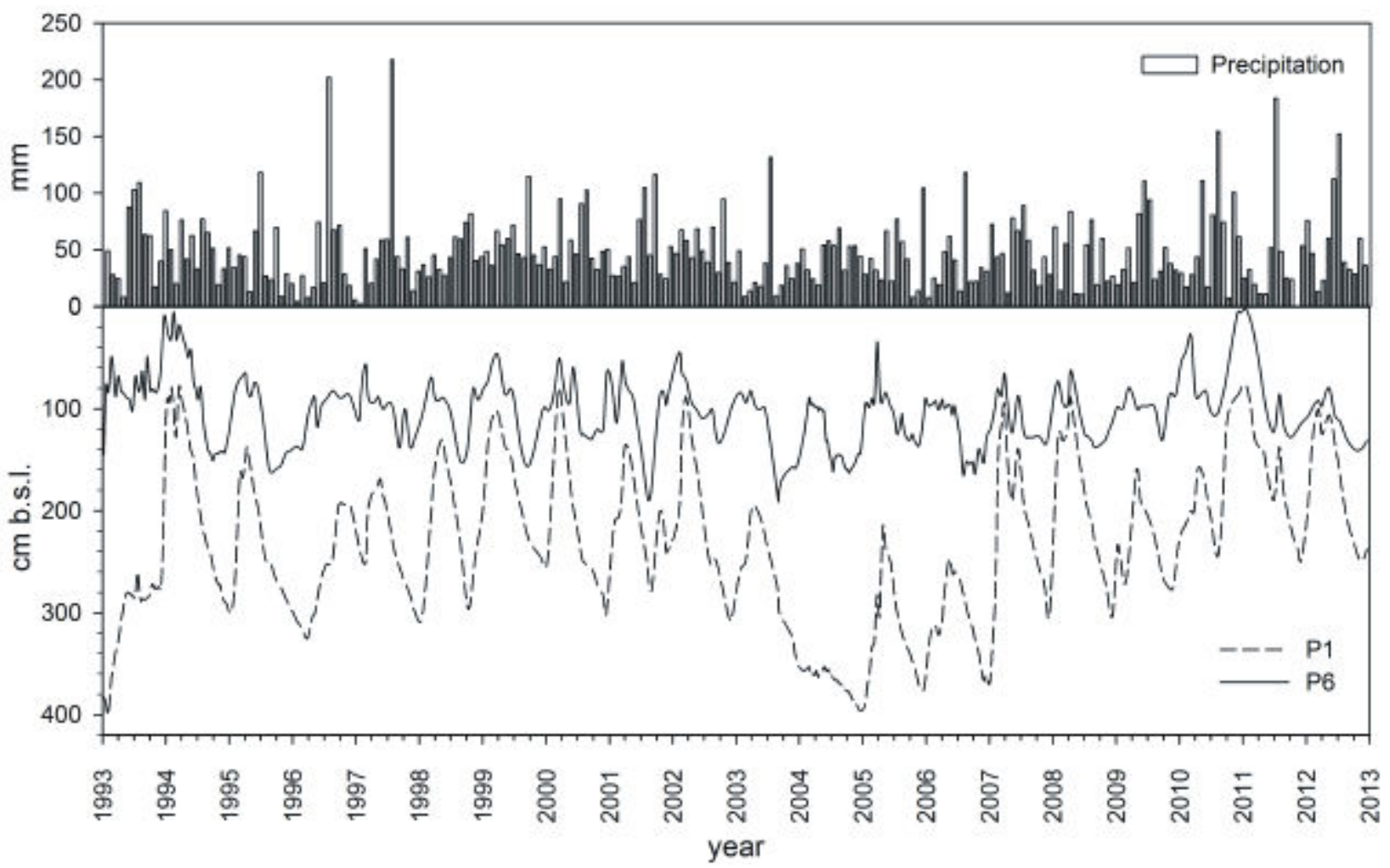

FIGURE 2. Water table fluctuation in the investigated toposequence soils relating to precipitation (P)

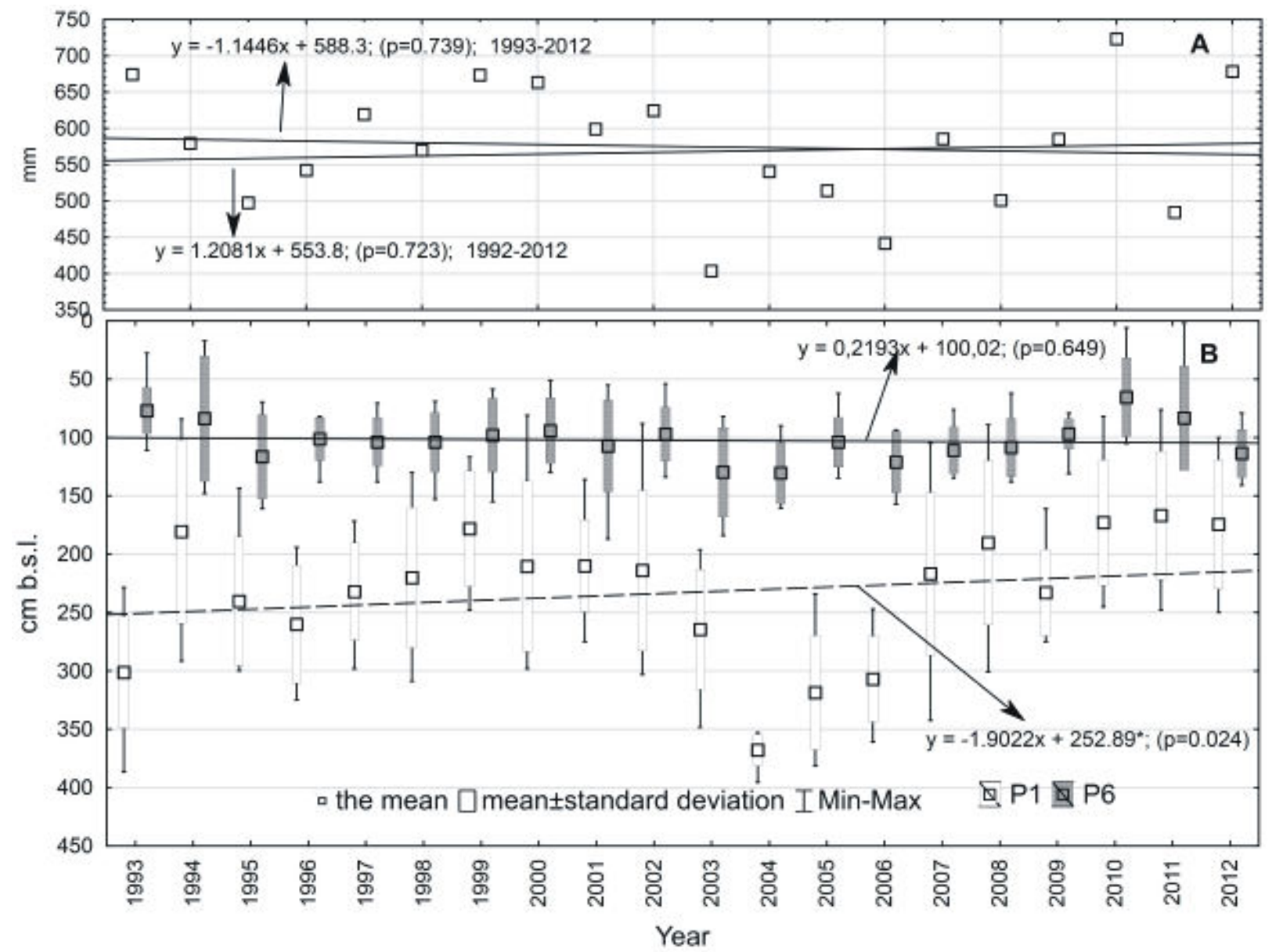

FIGURE 3. The mean annual water table depth and annual sum of precipitation in the investigated soils for 1993-2012 
apparent taking into account that in 2003 the annual sum of precipitation was $403 \mathrm{~mm}$. At the turn of winter and spring 2003/2004, no typical water table regeneration was observed, which resulted in a further decrease in the water table in 2004. From that year to 2008 a systematic rise of the water table was observed (Fig. 2, Fig. 3). Chen et al. (2002) analyzing annual precipitation and its relation to groundwater level variation have found that the mean annual water table depth is positively correlated with annual precipitation with a certain time delay. For the well located in Gleysols (P6), the lowest water table depths were observed in August 2001 and 2003, 187 and $184 \mathrm{~cm}$ below soil surface respectively.

The data presented in Figure 2 clearly show that both the depth of the water table and its amplitude were determined by the position of soil in the relief. The mean water table depth (MWT), the mean high water table depth (MHGL) and the mean low water table depth (MLGL) were deeper in P1 soil in comparison to P6 soil (Table 1). The MWT in Retisols P1 well was $233 \mathrm{~cm}$ below surface level (b.s.1.), whereas in Gleysols P6 well the corresponding value was at the depth of $102 \mathrm{~cm}$. The greatest water table fluctuations were observed in P1 well (from 76 to $400 \mathrm{~cm}$ ) in comparison to $\mathrm{P} 6$ pedon (from 2 to $187 \mathrm{~cm}$ ). This pattern is explained as being a result of lateral ground water flow from upper to lower parts of the slope. Simonson and Boersma (1972) have pointed out that water table amplitude and depth depend on the location of wells in the drainage soil sequence. Despite the greater amplitude of the water table in P1 well, the greatest variability of water table level was observed in P6 one. The value of the coefficient of variation in $\mathrm{P} 1$ was $22.6 \%$, whereas it was $27.7 \%$ in P6. This pattern indicates that there is faster interaction between the precipitation events and the water table depth in Gleysols at the footslope compared to that for Retisols at the slope summit. Rapid interaction between the rain-

TABLE 1. The mean water table depth (MWT), the mean high water table depth (MHWT), and the mean low water table depth (MLWT), the highest observed water table depth (HWT), and the lowest observed water table depth (LWT) and the coefficient of variation $(\mathrm{CV})$ in the investigated wells of catena

\begin{tabular}{llcc}
\hline Parameters & \multirow{2}{*}{ Unit } & \multicolumn{2}{l}{ Wells } \\
\cline { 3 - 4 } & & P1 & P6 \\
\hline MWT & cm b.s.l. & 232.9 & 102.3 \\
\hline MHWT & cm b.s.l & 150.8 & 59.3 \\
\hline MLWT & cm b.s.l & 309.1 & 143.0 \\
\hline HWT & cm b.s.1 & 76.0 & 2.0 \\
\hline LWT & cm b.s.l & 400.0 & 187.0 \\
\hline CV & $\%$ & 22.6 & 27.7 \\
\hline
\end{tabular}

fall events and the water table depths have been observed by Morgan and Stolt (2006).

Figure 3 shows the temporal changes in the mean annual water table depth (Fig. 3B) and annual sum of precipitation in the investigated soils (Fig. 3A). The lowest mean annual water table depths for P1 were noted in 2004, 2005 and $2006(368,319$ and $307 \mathrm{~cm}$ b.s.l. respectively), as a consequence of low precipitation in 2003, whereas the highest mean annual water table depths were in 2010 and 2011 (173 and $167 \mathrm{~cm}$ b.s.l. respectively). For P6 soil the lowest mean annual water table depths were in 2003 and 2004 (130 and $131 \mathrm{~cm}$ b.s.l. respectively), whereas the highest in 1993 and 2010 (77 and $65 \mathrm{~cm}$ b.s.l. respectively) (Fig. 3B). An attempt was made to approximate the changes in the mean annual water table depths by a linear relation. From the data presented in Fig. 3B, it is clear that over the 20 years the water table showed a tendency to increase $\left(1.9 \mathrm{~cm} \cdot \mathrm{year}^{-1}\right)$ in Retisol (profile P1) developed within the slope summit. This trend was statistically significant, at $\mathrm{p}$ (statistical significance) of 0.024 . As the trend analysis shows, in the Gleysol (profile P6) at the footslope the water table was dropping by about $0.2 \mathrm{~cm}$ per year. However, this relationship was not statistically significant $(p=0.649)$. Figure $3 \mathrm{~A}$ illustrates the tendency of changes in the annual sum of precipitation in the period 19922012 and 1993-2012. In the first period this sum showed a slight tendency to increase (not statistically significant), whereas in the second period it revealed a slight tendency to decrease (not statistically significant). This indicates that in the analyzed twentyyear period, the sum of annual precipitation did not change significantly. Also Kędziora (2008) did not observe significant changes in the sum of annual precipitation in 1951-2006 for Koło town and Poznań city.

Figure 4 shows temporal changes and trend lines of the mean monthly water table depth (Fig. 4B) and the monthly sum of precipitation in the investigated soils (Fig. 4A) for the period 1993-2012. In Retisol (profile P1) for the period 1993-2012 for each month the water table tendency to increase was noted. This trend was the most pronounced in the months January to April (from $-2.2 \mathrm{~cm} \cdot y^{2} a r^{-1}$ to $-3.6 \mathrm{~cm} \cdot \mathrm{year}^{-1}$ ), which may be related to the tendency of the monthly sum of precipitation to increase in December, January and February (Table 2). In the remaining months (May to December), for the period 1993-2012, there were also tendencies to increase the water table (from -0.8 $\mathrm{cm} \cdot$ year $^{-1}$ to $-2.0 \mathrm{~cm} \cdot \mathrm{year}^{-1}$ ). The tendency for the rise the water table in P1 soil, even in the vegetation season may be due to the lack of interaction between the water table and the active depth of the vegetation's rhizosphere. According to Komisarek (2000), there is still water 

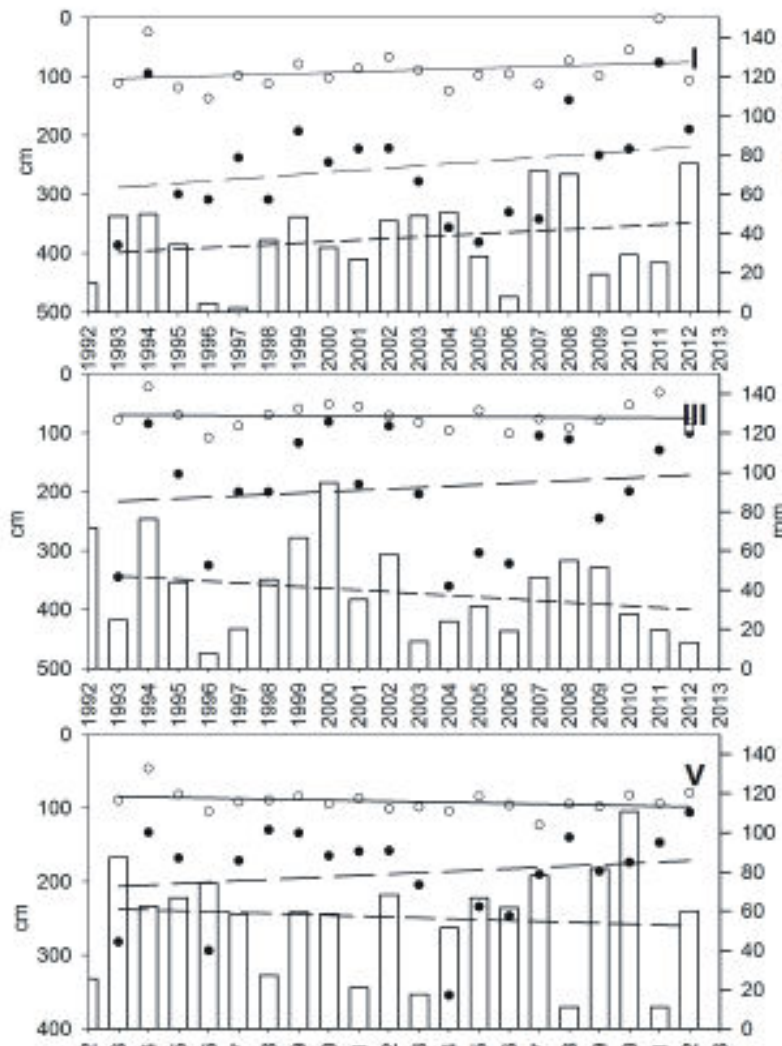

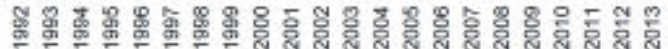
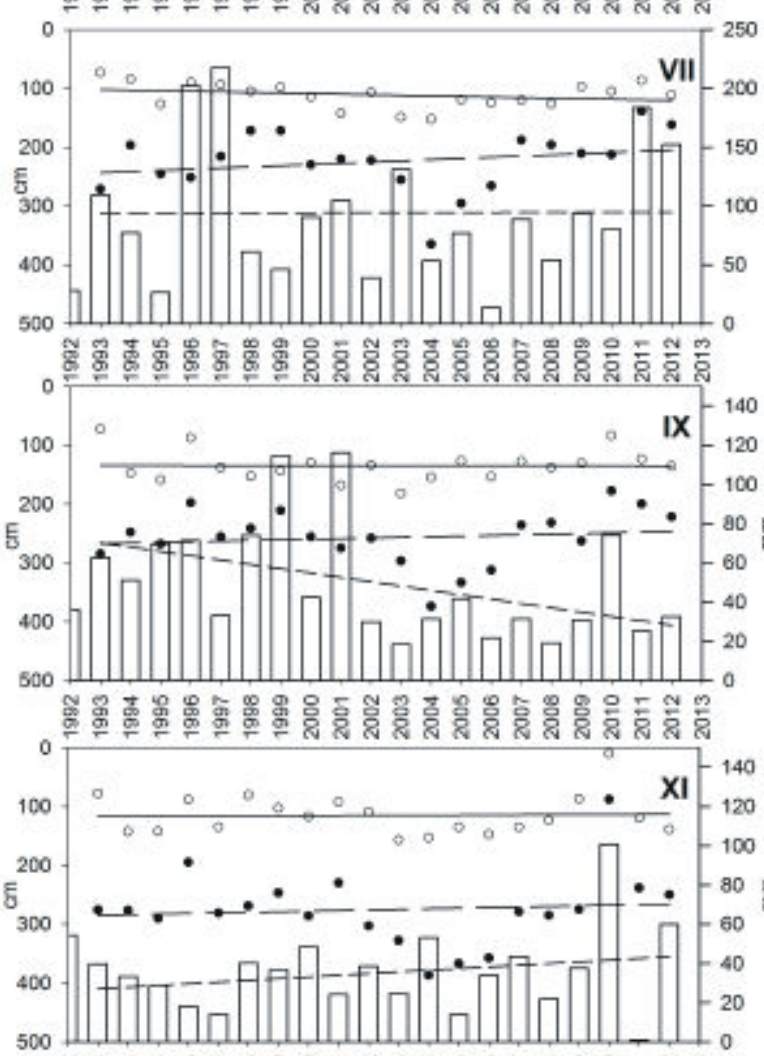

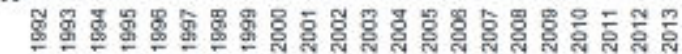

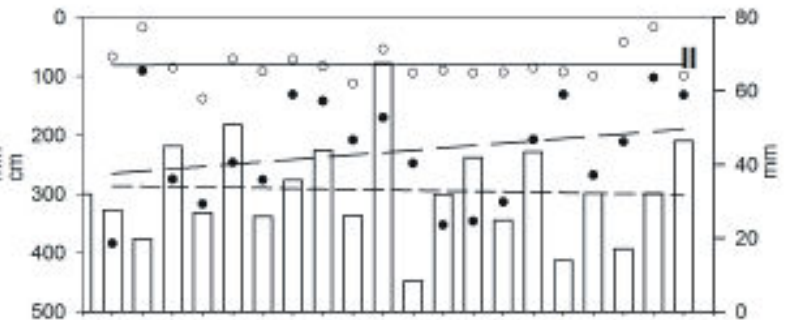

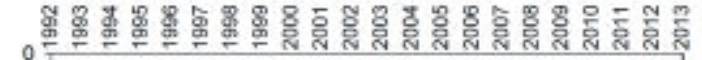

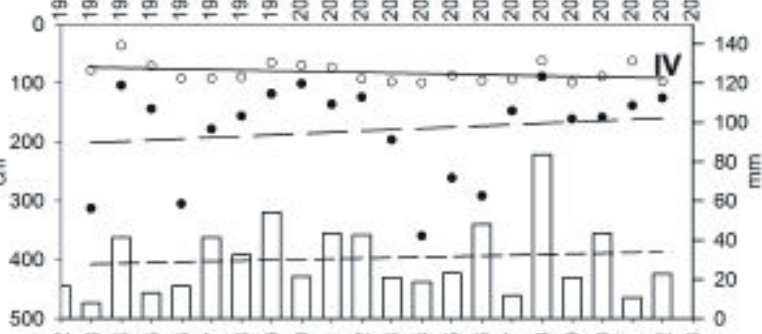

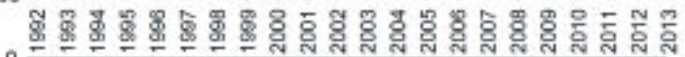

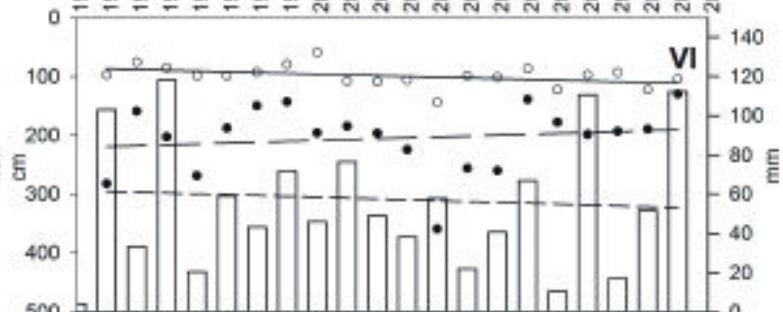

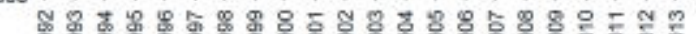
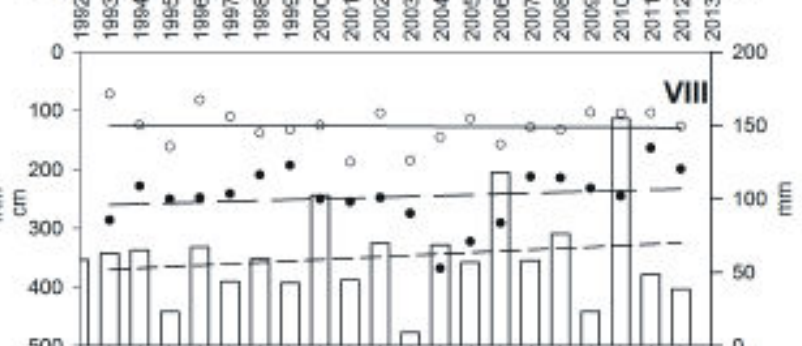

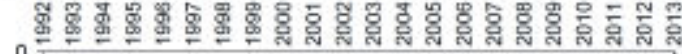

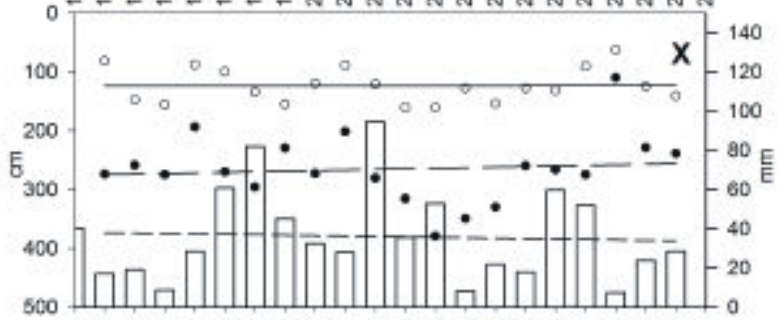

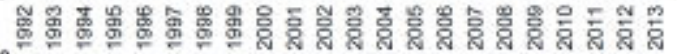

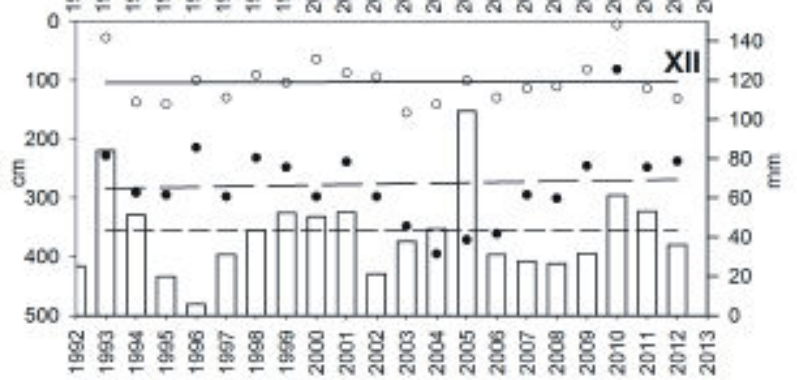

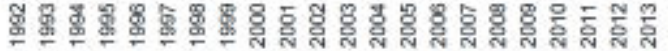

- P1 D P6 $\square$ Precipitation — trend line-P6 — - trend line-P1 _-- trend line-precipitation 
TABLE 2. Basic statistics of mean monthly water table depth and monthly sum of precipitation in the investigated soils and trend analysis for the period 1993-2012

\begin{tabular}{|c|c|c|c|c|c|c|}
\hline \multirow[t]{3}{*}{ Month } & \multicolumn{2}{|c|}{ Water table depth } & \multirow{3}{*}{$\begin{array}{l}\text { Precipitation } \\
(\mathrm{mm})\end{array}$} & \multicolumn{3}{|c|}{ The regression equation of linear trend analysis } \\
\hline & \multirow{2}{*}{$\begin{array}{l}\mathrm{P} 1 \\
\mathrm{~cm} \text { b.s.l. }\end{array}$} & \multirow[t]{2}{*}{ P6 } & & \multicolumn{2}{|l|}{ Water table depth $(\mathrm{cm})$} & \multirow{2}{*}{$\begin{array}{l}\text { Precipitation } \\
-(\mathrm{mm})\end{array}$} \\
\hline & & & & $\mathrm{P} 1$ & P6 & \\
\hline I & $\begin{array}{l}254 * \\
76-387 \\
\end{array}$ & $\begin{array}{l}89 * \\
2-137 \\
\end{array}$ & $\begin{array}{l}38 * \\
2-76 \\
\end{array}$ & $\begin{array}{l}y=-3.6579 x+292.11 \\
p=0.298\end{array}$ & $\begin{array}{l}y=-1.4738 x+104.95 \\
p=0.259\end{array}$ & $\begin{array}{l}y=0.7854 x+29.601 \\
p=0.354\end{array}$ \\
\hline II & $\begin{array}{l}228 * \\
91-384 \\
\end{array}$ & $\begin{array}{l}80 * \\
17-138 \\
\end{array}$ & $\begin{array}{l}33 * \\
8-68 \\
\end{array}$ & $\begin{array}{l}y=-3.9519 x+269.19 \\
p=0.263\end{array}$ & $\begin{array}{l}y=-0.14 x+81.25 \\
p=0.0907\end{array}$ & $\begin{array}{l}y=-0.1181 x+34.343 \\
p=8.36\end{array}$ \\
\hline III & $\begin{array}{l}194 * \\
81-361\end{array}$ & $\begin{array}{l}72 * \\
21-108\end{array}$ & $\begin{array}{l}* \\
98-94 \\
\end{array}$ & $\begin{array}{l}y=-2.3579 x+218,51 \\
p=0.535\end{array}$ & $\begin{array}{l}y=0.299 x+68.379 \\
p=0.741\end{array}$ & $\begin{array}{l}y=-0.8956 x+48.055 \\
p=0.331\end{array}$ \\
\hline IV & $\begin{array}{l}180 * \\
89-360\end{array}$ & $\begin{array}{l}82 * \\
36-99\end{array}$ & $\begin{array}{l}31 * \\
8-84 \\
\end{array}$ & $\begin{array}{l}y=-2.2176 x+203.53 \\
p=0.492\end{array}$ & $\begin{array}{l}y=0.9545 x+72.102 \\
p=0.1495\end{array}$ & $\begin{array}{l}y=0.3174 x+27.561 \\
p=0.675\end{array}$ \\
\hline $\mathrm{V}$ & $\begin{array}{l}189^{*} \\
105-355\end{array}$ & $\begin{array}{l}91 * \\
46-123\end{array}$ & $\begin{array}{l}57 * \\
11-111 \\
\end{array}$ & $\begin{array}{l}y=-1.8474 x+208.28 \\
p=0.469\end{array}$ & $\begin{array}{l}y=0.731 x+83.399 \\
p=0.208\end{array}$ & $\begin{array}{l}y=-0.4481 x+61.463 \\
p=0.674\end{array}$ \\
\hline VI & $\begin{array}{l}205^{*} \\
130-359\end{array}$ & $\begin{array}{l}99 * \\
59-144\end{array}$ & $\begin{array}{l}57^{*} \\
10-118\end{array}$ & $\begin{array}{l}y=-1.4823 x+220.71 \\
p=0.514\end{array}$ & $\begin{array}{l}y=1.2888 x+85.719 \\
p=0.067\end{array}$ & $\begin{array}{l}y=-0.433 x+61.868 \\
p=0.743\end{array}$ \\
\hline VII & $\begin{array}{l}225^{*} \\
139-365\end{array}$ & $\begin{array}{l}112 * \\
73-153\end{array}$ & $\begin{array}{l}94 * \\
13-206 \\
\end{array}$ & $\begin{array}{l}y=-2.0402 x+245,96 \\
p=0.323\end{array}$ & $\begin{array}{l}y=0.9867 x+101.17 \\
p=0.252\end{array}$ & $\begin{array}{l}y=0.0924 x+94.04 \\
p=0.968\end{array}$ \\
\hline VIII & $\begin{array}{l}246^{*} \\
164-368 \\
\end{array}$ & $\begin{array}{l}127 * \\
72-187\end{array}$ & $\begin{array}{l}62 * \\
9-154 \\
\end{array}$ & $\begin{array}{l}y=-1.4202 x+261.4 \\
p=0.447\end{array}$ & $\begin{array}{l}y=0.2429 x+124.14 \\
p=0.842\end{array}$ & $\begin{array}{l}y=0.989 x+51.322 \\
p=0.459\end{array}$ \\
\hline IX & $\begin{array}{l}257^{*} \\
178-374 \\
\end{array}$ & $\begin{array}{l}135^{*} \\
73-182\end{array}$ & $\begin{array}{l}50 * \\
18-116 \\
\end{array}$ & $\begin{array}{l}y=-1.0624 x+268.41 \\
p=0.580\end{array}$ & $\begin{array}{l}y=0.0481 x+134.07 \\
p=0.965\end{array}$ & $\begin{array}{l}y=-2.1966 x+72.593 \\
p=0.049\end{array}$ \\
\hline $\mathrm{X}$ & $\begin{array}{l}265^{*} \\
110-380\end{array}$ & $\begin{array}{l}124^{*} \\
63-161\end{array}$ & $\begin{array}{l}36^{*} \\
7-94 \\
\end{array}$ & $\begin{array}{l}y=-0.9857 x+275.75 \\
p=0.974\end{array}$ & $\begin{array}{l}y=-0.0386 x+124.31 \\
p=0.676\end{array}$ & $\begin{array}{l}y=-0.2071 x+38.308 \\
p=0.832\end{array}$ \\
\hline XI & $\begin{array}{l}275^{*} \\
88-387 \\
\end{array}$ & $\begin{array}{l}115^{*} \\
10-157 \\
\end{array}$ & $\begin{array}{l}36^{*} \\
1-101 \\
\end{array}$ & $\begin{array}{l}y=-1.0014 x+285.97 \\
p=0.698\end{array}$ & $\begin{array}{l}y=-0.1843 x+116.71 \\
p=0.897\end{array}$ & $\begin{array}{l}y=0.8777 x+26.315 \\
p=0.293\end{array}$ \\
\hline XII & $\begin{array}{l}276^{*} \\
82-396\end{array}$ & $\begin{array}{l}103 * \\
6-156\end{array}$ & $\begin{array}{l}43 * \\
6-104\end{array}$ & $\begin{array}{l}y=-0.8019 x+284.84 \\
p=0.772\end{array}$ & $\begin{array}{l}y=-0.0824+104.1 \\
p=0.957\end{array}$ & $\begin{array}{l}y=0.0026 x+43.251 \\
p=0.998\end{array}$ \\
\hline
\end{tabular}

*mean; minimum-maximum, $\mathrm{y}$ - water table depth or precipitation, $\mathrm{x}$ - number of months, $\mathrm{p}$ - statistical significance.

outflow to the deeper parts of the soil profile when the spring drying up of the upper soil horizons begins, especially in soils located in upper part of slopes. In footslope Gleysol (profile P6), a decreasing water table depth tendency was observed in the vegetation season for the period 1993-2012. This trend may be due to the impact of water table on the soil water content of the root zone, which is used in the process of evapotranspiration. According to Kędziora (2008), evapotranspiration is increasing year by year, which seems to have a significant impact on water table in Gleysols. In the remaining months (October to February), for the period 1993-2012, an increasing water table tendency was detected, which was most pronounced in January $\left(-1.5 \mathrm{~cm} \cdot \mathrm{year}^{-1}\right)$.

\section{CONCLUSIONS}

1. The mean water table depth, the mean high water table depth and the mean low water table depth depend on the relief soil position. The Retisols located in upper part of the slope are characterized by a deeper water table depth in comparison to Gleysols located in lower part of the slope where water table is shallow.

2. Higher amplitude of water table was observed in Retisols than in Gleysols, but the variability of water table level was higher in the soils at the footslope compared to those developed within the summit of the slope.

3. A tendency for the mean annual water table depth to rise was observed in Retisols developed within the summit of the slope. In Gleysols at the footslope no tendency of changes in the mean annual water table was noted.

4. The water table showed a tendency to increase in each month in Retisols for the period 1993-2012. This trend was the best marked from January to April, which may be related to the tendency for the monthly sum of precipitation to increase in December, January and February.

5. The water table depth revealed a tendency to decrease in the Gleysol at the footslope, in the period 1993-2012 in the vegetation season. This trend may be due to the impact of water table on the soil water content of the root zone, which is used in the process of evapotranspiration. 


\section{REFERENCES}

Almedeij J., Al-Ruwaih F., 2006. Periodic behavior of groundwater level fluctuations in residential areas. Journal of Hydrology 328: 677-684.

Buol S., Southard R., Graham R., McDaniel P., 2011. Soil genesis and classification: Wiley-Blackwell.

Chen Z., Grasby S., Osadetz K., 2002. Predicting average annual groundwater levels from climatic variables: an empirical model. Journal of Hydrology 260: 102-117.

Hanna A., Harlan P., Lewis D., 1983. Effect of slope on water balance under center-pivot irrigation. Soil Science Society of America Journal 47: 760-764.

IPCC, 2014. Intergovernmental Panel on Climate Change. Summary for Policymakers, In: Climate Change 2014, Mitigation of Climate Change. Cambridge, United Kingdom and New York, NY, USA: Cambridge University Press.

IUSS Working Group WRB, 2015. World Reference Base for Soil Resources 2014, update 2015. International soil classification system for naming soils and creating legends for soil maps. World Soil Resources Reports No. 106. FAO, Rome.

Jan C.-D., Chen T.-H., Lo W.-C., 2007. Effect of rainfall intensity and distribution on groundwater level fluctuations. Journal of Hydrology 332: 348-360.

Kędziora A., 2008. Bilans wodny krajobrazu konińskich kopalni odkrywkowych w zmieniających się warunkach klimatycznych. Roczniki Gleboznawcze - Soil Science Annual 59(2): 104-118.

Khan F., Fenton T., 1994. Saturated zones and soil morphology in a Mollisol catena of central Iowa. Soil Science Society of America Journal 58: 1457-1464.
Komisarek J., 2000. Kształtowanie się właściwości gleb płowych i czarnych ziem oraz chemizmu wód gruntowych w katenie falistej Pojezierza Poznańskiego. Rozprawy Naukowe, Zeszyt 307, Roczniki Akademii Rolniczej w Poznaniu.

Komisarek J., Kozłowski M., 2008. Zastosowanie modelu symulacyjnego SWAP do określenia uwilgotnienia gleb o opadowo-retencyjnym reżimie wodnym. Roczniki Gleboznawcze - Soil Science Annual 59: 119-129.

Krogulec E., Zabłocki S., 2015. Relationship between the environmental and hydrogeological elements characterizing groundwater-dependent ecosystems in central Poland. Hydrogeology Journal 23(7): 1587-1602.

Marcinek J., Kaźmierowski C., Komisarek J., 1998. Rozmieszczenie gleb i zróżnicowanie ich właściwości w katenie falistej moreny dennej Pojezierza poznańskiego. Zeszyty Problemowe Postępów Nauk Rolniczych 460: 53-74.

Morgan C., Stolt M., 2006. Soil morphology-water table cumulative duration relationships in southern New England. Soil Science Society of America Journal 70: 816-824.

Simonson G., Boersma L., 1972. Soil morphology and water table relations: II. Correlation between annual water table fluctuations and profile features. Soil Science Society of America Journal 36: 649-653.

Stasik R., Korytowski M., Liberacki D., 2016. Trends in groundwater level changes in small forest catchments of Wielkopolska. Journal of Ecological Engineering 17(4): 99-106.

Zobeck, T., Ritchie A., 1984. Analysis of long-term water table depth records from a hydrosequence of soils in central Ohio. Soil Science Society of American Journal 48: 119-125.

Received: July 18, 2017

Accepted: November 20, 2017

Associated editor: t. Uzarowicz

\title{
Czasowe zmiany zalegania zwierciadła wód gruntowych w glebach układu toposekwencyjnego Pojezierza Poznańskiego (zachodnia Polska)
}

\begin{abstract}
Streszczenie: W pracy przedstawiono wyniki badań czasowych trendów zalegania zwierciadła wód gruntowych w układzie toposekwencyjnym gleb płowych i czarnych ziem. Analizę czasowych trendów zalegania zwierciadła wód gruntowych przeprowadzono na podstawie linowej regresji. Wyniki badań wskazują, że głębokości średnich stanów wód gruntowych, średnich najwyższych stanów wód gruntowych i średnich najniższych stanów wód gruntowych były większe w glebach w górnym położeniu wyniesienia dennomorenowego w porównaniu do gleb położonych u podnóża stoku. Większą amplitudę zmian głębokości zalegania zwierciadła wód gruntowych obserwowano w glebie płowej zaciekowej niż w czarnej ziemi natomiast większa zmienność stanów zwierciadła wód gruntowych była w glebach podnóża stoku aniżeli w glebach kulminacji stoku. W glebie płowej zaciekowej dla każdego miesiąca w okresie 1993-2012 stwierdzono tendencje płytszego zalegania wód gruntowych. Trendy te były największe w miesiącach od stycznia do kwietnia, co może wynikać z tendencji wzrostowej sumy opadów w miesiącach grudzień-luty. W czarnej ziemi u podnóża stoku w latach 1993-2012 dla okresu wegetacyjnego uzyskano tendencję do obniżania głębokości zalegania zwierciadła wód gruntowych, co może wynikać z wpływu wód gruntowych na zawartość wody strefy korzenienia się roślin, która jest wykorzystywana w procesie ewapotranspiracji.
\end{abstract}

Stowa kluczowe: gleby płowe zaciekowe, czarne ziemie, toposekwencja, wody gruntowe, trend 